\title{
INTERNATIONAL LEGAL COOPERATION OF THE REPUBLIC OF UZBEKISTAN WITH THE COUNTRIES OF THE PERSIAN GULF WITHIN THE FRAMEWORK OF REGIONAL INTERNATIONAL ORGANIZATIONS
}

Mirkhamidova Makhinara, Independent researcher of the University of World Economy and diplomacy, Republic of Uzbekistan mmirhamidova@mail.ru

ORCID ID: orcid.org/0000-0003-0619-1306 Crossref http://dx.doi.org/10.26739/2433-202x Issue DOI http://dx.doi.org/10.26739/2433-202x-2017-7-7 Article DOI http://dx.doi.org/10.26739/2433-202x-2017-7-7-3

Abstract: The article is devoted to the review and analysis of the main areas of cooperation of the Republic of Uzbekistan with the countries of the Persian Gulf within the framework of the relevant regional international organizations, namely the Organization of Islamic Cooperation (OIC), the Islamic Organization for Education, Science and Culture (ISESCO) and the Islamic Development Bank (IDB).

Keywords: Persian Gulf, OIC, ISESCO, IDB, IDB Special Program for Central Asia (SPCA) 
The Persian Gulf during the last quarter of the 20th century seems to be one of the most tense regions of the world, politically, socially and internationally. Here, in the zone of the world's richest oil deposits, the flow and conditions of oil supplies to international markets are largely formed. ${ }^{1}$

Great attention is paid to the countries of the Persian Gulf by the development of cooperation in the framework of regional organizations. To date, a number of organizations are functioning within the region, namely the Organization of the Islamic Conference (OIC), the League of Arab States (LAS), the Council of Cooperation of the Arab States of the Persian Gulf (GCC). These organizations have a great deal in the region and directly influence the adoption of certain political decisions.

The most important role is played by the League of Arab States (LAS), an international organization that unites Arab states, as well as a number of friendly non-Arabs, in which the Arabic language is one of the official languages. ${ }^{2}$ The aim of the LAS is to strengthen the ties between the states participating in it, to develop a unified political line for cooperation between them, to protect their independence and sovereignty and in general to consider the cases and interests of the Arab countries. At the same time, cooperation is not limited to political aspects and includes also economic, financial, communication, cultural, social and health interactions. In addition, cooperation includes issues of citizenship, passports, visas, extradition of criminals. It can also be noted that in 1950 the League received observer status at the UN.

\footnotetext{
1 Черкасский Я. Региональная безопасность Персидского залива. / / Белорусский журнал международного права и международных отношений № 4. - С. 73

2 Official website of the Organization is http://www.arableagueonline.org/las/index.jsp
} 
Another organization in which the Gulf countries play an important role is the Organization of the Petroleum Exporting Countries (OPEC), an international intergovernmental organization set up by the oil-producing countries to stabilize oil prices. ${ }^{3}$ The goal of OPEC is to coordinate activities and develop a common policy on oil production among the member countries of the organization, maintain stable oil prices, ensure stable supplies of oil to consumers, and benefit from investment in the oil industry.

Another organization in which the Gulf countries play an important role is the Organization of Islamic Cooperation (OIC), an international organization of Islamic countries (until 2011, the Organization of the Islamic Conference (OIC)).

OIC is the largest and most influential official government Muslim international organization. Initially, it included 25 states of Asia and Africa and the Palestine Liberation Organization.

The OIC has a number of independent organizations established by the decisions of its conferences and whose activities are coordinated by the General Secretariat, for example, the Islamic Development Bank, the Islamic Organization for Education, Science and Culture.

It should be noted that the OIC is currently undergoing a period of modernization. In this regard, at the next OIC Summit in Dakar (Senegal) in March 2008, a new Charter of the Organization was adopted.4 On June 28, 2011, the Organization of the Islamic Conference was renamed the Organization of Islamic Cooperation (OIC) by the decision of the OIC, the 38th session of the Council of Foreign Ministers (CMFA) held in Astana.

3 Official website of the Organization is http://www.opec.org/opec_web/en/ 4Official website of the Organization is http://www.oic-oci.org 
There is an increase in the importance of this organization in the international arena and the strengthening of its influence on world political processes. ${ }^{5}$

The Islamic Organization for Education, Science and Culture (abbreviated ISESCO), an organization established by the Organization of the Islamic Conference (OIC) in May 1979, plays an equally important role in the Persian Gulf region. The organization was created with the aim of ensuring Islamic solidarity, calling for it, as well as giving it an actual and modern form. It can be said that I It can also be noted that in 1950 the League received observer status at the UN.

Another organization in which the Gulf countries play an important role is the Organization of the Petroleum Exporting Countries (OPEC), an international intergovernmental organization set up by the oil-producing countries to stabilize oil prices. The goal of OPEC is to coordinate activities and develop a common policy on oil production among the member countries of the organization, maintain stable oil prices, ensure stable supplies of oil to consumers, and benefit from investment in the oil industry.

Another organization in which the Gulf countries play an important role is the Organization of Islamic Cooperation (OIC), an international organization of Islamic countries (until 2011, the Organization of the Islamic Conference (OIC)).

OIC is the largest and most influential official government Muslim international organization. Initially, it included 25 states of Asia and Africa and the Palestine Liberation Organization. The OIC has a number of independent organizations established by the decisions of its conferences and

5 Балашов А., ОИК: Институциональный дизайн и основные направления развития // Ислам в современном мире http:/ / www.islam.ru/pressclub/analitika/okinde/ 
whose activities are coordinated by the General Secretariat, for example, the Islamic Development Bank, the Islamic Organization for Education, Science and Culture.

It should be noted that the OIC is currently undergoing a period of modernization. In this regard, at the next OIC Summit in Dakar (Senegal) in March 2008, a new Charter of the Organization was adopted. On June 28, 2011, the Organization of the Islamic Conference was renamed the Organization of Islamic Cooperation (OIC) by the decision of the OIC, the 38th session of the Council of Foreign Ministers (CMFA) held in Astana. There is an increase in the importance of this organization in the international arena and the strengthening of its influence on world political processes.

The Islamic Organization for Education, Science and Culture (abbreviated ISESCO), an organization established by the Organization of the Islamic Conference (OIC) in May 1979, plays an equally important role in the Persian Gulf region. The organization was created with the aim of ensuring Islamic solidarity, calling for it, as well as giving it an actual and modern form. It can be said that ISESCO is a Muslim analogue of UNESCO. ${ }^{6}$

The leading role in the development of regional cooperation between the countries of the Persian Gulf is played by the Cooperation Council of the Arab States of the Gulf (GCC), the regional closed international organization. ${ }^{7}$ In the official name of the organization the word Persian is absent, since the Arab states prefer to call this bay Arab. ${ }^{8}$ The main goal of the organization is coordination, cooperation and integration in all economic, social and cultural

6 Official website of the Organization is http://www.isesco.org.ma/

7 http:/ / www.gcc-sg.org/CHARTER.html

8 Presently there are 18 ISESCO Chairs all over the world.

Social science and humanities

M. Mirkhamidova 
affairs. In addition, the plans include the creation of an integrated defense force for rapid deployment.

Thus, the cooperation of the countries of the Persian Gulf continues to develop dynamically and expand, taking into account modern realities and international cooperation trends.

The Republic of Uzbekistan pays special attention to the development of cooperation with the countries of the Persian Gulf within the framework of some of the above-mentioned organizations.

Concerning cooperation within the framework of the OIC, first of all, the importance of the Central Asian OIC member countries, including the Republic of Kazakhstan, the Kyrgyz Republic, the Republic of Tajikistan, Turkmenistan and the Republic of Uzbekistan.

The Central Asian OIC member states are located in an important geostrategic region. Therefore, the Central Asian OIC Member States need to develop a practical cooperation strategy and an appropriate action plan through which they can use existing opportunities within the OIC to advance their activities in the area of social and economic development.

Uzbekistan's cooperation with ISESCO is developing as well. In 2007, Tashkent was elected the International Islamic Organization for Education, Science and Culture (ISESCO) in Tashkent, the capital of the world of Islamic culture.

At the 43rd session of the Council of Foreign Ministers of OIC, the President of the Republic of Uzbekistan Sh. Mirziyoyev put forward an initiative to establish a special department of the Islamic Organization for Education, Science and Culture (ISESCO) within the Tashkent Islamic University. It was fully supported by all member countries and the OIC 
General Secretariat. In the speeches of many participants of the meeting of the Foreign Ministers Council, the timeliness and thoughtfulness of the proposal of the leadership of the republic was emphasized, the implementation of which should serve more active cooperation between Uzbekistan, member countries and relevant OIC structures in the study of the historical, cultural and scientific heritage of the great thinkers of the East.

In connection with this, the Tashkent Islamic University worked with the Islamic Organization for Education, Science and $t$ the 43rd session of the Council of Foreign Ministers of OIC, President of the Republic of Uzbekistan Sh. Mirziyoyev put forward an initiative to establish a special department of the Islamic Organization for Education, Science and Culture (ISESCO) within the Tashkent Islamic University. It was fully supported by all member countries and the OIC General Secretariat. In the speeches of many participants of the meeting of the Foreign Ministers Council, the timeliness and thoughtfulness of the proposal of the leadership of the republic was emphasized, the implementation of which should serve more active cooperation between Uzbekistan, member countries and relevant OIC structures in the study of the historical, cultural and scientific heritage of the great thinkers of the East.

In this regard, the Tashkent Islamic University worked with the Islamic Organization for Education, Science and Culture (ISESCO) to establish a special department at the university ISESCO. On May 24, 2017, a Memorandum of Understanding was signed with the participation of ISESCO Director General Dr. Abdulaziz bin Usman al-Tuvejri and the Rector of the Tashkent Islamic University Professor Ravshan Abdullayev. According 
to the signed document, the Tashkent Islamic University became a member of the Federation of Universities of the Islamic World under ISESCO.

The department will carry out tasks related to comprehensive and scientific study of Islam, culture, historical and national heritage of our Motherland, its traditions and customs, and a scientific analysis of contemporary religious processes. The main priorities of the department are the preparation of bachelors and masters in the field of enlightenment Islam, the fight against religious extremism and terrorism, the destructive activity of certain currents of modern Islam. It is also planned to release specialists of museum and archival funds, religious and historical complexes, as well as specialists in the field of Muslim architecture (with knowledge of the Muslim historical, cultural and spiritual heritage not only of Uzbekistan, but of all Central Asia.

Among the department's tasks is also a systematic study of the problems that arise in the Islamic world in the sphere of religion, the use of the scientific heritage of scientists of Central Asia in the fight against religious extremism and terrorism, and also the functions of a center for advanced training for researchers. It should also be noted that the ISESCO chair will become a place of practice for employees and workers in the sphere of culture, religious and historical complexes, as well as guides specializing in the history, culture, spirituality of the Islamic world.

Uzbekistan is also developing cooperation within the framework of the IDB. IDB was established in December 1973 at a conference of finance ministers of the organization, its members are 56 OIC member states. The Bank has three regional offices in the cities of Rabat (Morocco), Kuala Lumpur (Malaysia) and Almaty (Kazakhstan). 
By the beginning of March 2003, in the Central Asian region, the Bank approved projects worth more than US \$ 420 million. Of these, 94.6\% were investment projects, $5.4 \%$ fell on technical assistance, trade and financial operations and special assistance operations. Given the geographic location of Central Asia and its mission in the region, the IDB has concentrated most of its loans in the transport sector.

IDB also offers training for officials of the countries of the region to enhance their professionalism, provides experts to advise member countries in various areas of governance and development. To this end, the IDB organizes seminars, working meetings through the Technical Cooperation Branch (OTC) and the Islamic Institute for Research and Training (IRTI). The Bank conducts seminars and consultations on WTO agreements, as well as courses on trade policy for representatives of governments of IDB member countries.

IDB, with the assistance of the Azerbaijani government, has developed a "Special Program for Central Asia" (SPCA). ${ }^{9}$ This program represents the regional program of the Islamic Development Bank Group aimed at supporting cooperation between participating countries in Central Asia, promoting trade, enhancing competitiveness and stimulating economic growth in accordance with the Sustainable Development Goals (LDCs).

SPCA covers six participating countries, namely: Azerbaijan, Kazakhstan, Kyrgyz Republic, Tajikistan, Turkmenistan and Uzbekistan. Despite the fact that Azerbaijan is geographically located in the South Caucasus, it is included in the Program due to the similarity of the program's

9 Специальная программа для Центральной Азии (СПЦА) Повышение конкурентоспособности, усиление торгово - экономического роста (2016-2020) 
tasks with other countries in the Region. The total cost of the "Special Program for Central Asia" is $\$ 6$ billion. It includes a number of projects in the fields of transport, energy, agriculture and trade, which are planned to be implemented between 2016 and 2020 .

Regarding cooperation with Uzbekistan, Uzbekistan has been a member of the IDB since 2003.

IDB allocated \$ 300 million for the construction of rural rural houses in Uzbekistan. Cooperation with IDB for the implementation of the Program for the construction of residential buildings in rural areas on the basis of typical DB allocated \$ 300 million for the construction of rural rural houses in Uzbekistan. Cooperation with IDB for the implementation of the Program for the construction of houses in rural areas on the basis of standard projects has been conducted since 2014. Within the framework of the agreement in 20172021, it is planned to build more than 6.4 thousand houses under the updated standard projects, $110.52 \mathrm{~km}$ of inbound and inland roads, and $197.80 \mathrm{~km}$ of drinking water systems in 6 regions of the republic. IDB's funds are allocated to Uzbekistan for 15 years, including a two-year grace period.

A Memorandum of Understanding was signed between the Government of the Republic of Uzbekistan and the Islamic Development Bank on the establishment of the Imam Bukhari International Research Center.

Therefore, Uzbekistan develops cooperation with the countries of the Persian Gulf. It is noteworthy that most intensively this cooperation is developing in the field of economics and culture. 


\section{References}

1. Черкасский Я. Региональная безопасность Персидского залива. //Белорусский журнал международного права и международных отношений № 4. - С. 73

2. Official website of the Organization is http://www.arableagueonline.org/las/index.jsp

3. Official website of the Organization is http://www.opec.org/opec_web/en/

4. Official website of the Organization is http://www.oic-oci.org

5. Балашов А., ОИК: Институциональный дизайн и основные направления развития // Ислам в современном мире http://www.islam.ru/pressclub/analitika/okinde/

6. Official website of the Organization is http://www.isesco.org.ma/

7. http://www.gcc-sg.org/CHARTER.html

8. Presently there are 18 ISESCO Chairs all over the world.

9. Специальная программа для Центральной Азии (СПЦА) Повышение конкурентоспособности, усиление торгово экономического роста (2016-2020) 